\title{
PENGARUH DAUN TREMBILUNGAN (Begonia hirtella Link) TERHADAP Candida albicans
}

\author{
${ }^{1}$ Risa Wahyuningsih, S.ST., M.Si. \\ ${ }^{1}$ Stikes Borneo Cendekia Medika Pangkalan Bun \\ ${ }^{1}$ Email : risa.analisbcm16@yahoo.co.id
}

\begin{abstract}
ABSTRAK
Fungi yang merugikan dapat menyebabkan penyakit, salah satunya adalah Candida albicans. Penyakit yang disebabkan Candida disebut kandidiasis. Kandidiasis merupakan infeksi yang paling sering diantara seluruh infeksi jamur (Mandal et al., 2004). Pengobatan penyakit yang disebabkan oleh infeksi fungi menggunakan antibiotik. Penggunaan antibiotik tersebut menyebabkan resistensi dan dapat menimbulkan efek samping yang kurang baik untuk kesehatan. Sehingga perlu ditemukan pengobatan alternatif menggunakan bahan alam menggunakan daun Begonia hirtella. Penelitian ini bertujuan untuk mengetahui pengaruh ekstrak $n$ heksan, etil asetat dan etanol daun $B$. hirtella terhadap $C$. albicans. Hasil pengukuran diameter zona hambat konsentrasi 1000 ppm masing-masing ekstrak terhadap C. albicans diperoleh rata-rata zona hambat ekstrak $n$-heksan (12 mm), ekstrak etil asetat $(13 \mathrm{~mm})$ dan ekstrak etanol (12.5 mm).
\end{abstract}

Kata Kunci : Candida albicans, Begonia hirtella, antifungi

\section{EFFECT OF TREMBILUNGAN LEAF (Begonia hirtella Link) On Candida albicans}

\begin{abstract}
Adverse fungi can cause disease, one of which is Candida albicans. The disease caused by Candida is called candidiasis. Candidiasis is the most common infection among all fungal infections (Mandal et al., 2004). Treatment of diseases caused by fungal infections using antibiotics. The use of antibiotics causes resistance and can cause side effects that are not good for health. So that alternative treatments need to be found using natural ingredients using Begonia hirtella leaves. This study aims to determine the effect of n-hexane, ethyl acetate and ethanol extracts of B. hirtella
\end{abstract}


leaves on $C$. albicans. The measurement results of inhibition zone concentrations of 1000 ppm each extract against C. albicans obtained an average inhibition zone of $\mathrm{n}$-hexane extract (12 mm), ethyl acetate extract $(13 \mathrm{~mm})$ and ethanol extract (12.5 $\mathrm{mm})$.

Keywords: Candida albicans, Begonia hirtella, antifungal

\section{PENDAHULUAN}

Kingdom fungi ada yang
menguntungkan dan merugikan.
Fungi yang merugikan dapat
menyebabkan penyakit, salah
satunya adalah Candida albicans.
Penyakit yang disebabkan Candida
disebut kandidiasis. Kandidiasis
merupakan infeksi yang paling
sering diantara seluruh infeksi jamur
(Mandal et al., 2004). C. albicans
merupakan organisme komensal
umum dalam usus, mulut dan vagina.
Jamur ini menyebabkan spektrum
penyakit yang luas seperti sariawan
mulut, vaginitis endokarditis dan
septikemia (Neal, 2006). Pada
kandidiasis superfisial akan
mengalami peningkatan Candida
yang menyebabkan kerusakan pada
kulit, sehingga terjadi invasi lokal
oleh yeast dan pseudohyphae. Pada
kandidiasis sistemik Candida masuk
ke aliran darah ketika imunitas host
sedang lemah, dari sistem sirkulasi

Candida dapat menginfeksi ginjal dan jantung (Brooks, 2007).

Pengobatan penyakit yang disebabkan oleh infeksi fungi menggunakan antibiotik. Penggunaan antibiotik tersebut menyebabkan resistensi dan dapat menimbulkan efek samping yang kurang baik untuk kesehatan. Sehingga perlu ditemukan pengobatan alternatif menggunakan bahan alam menggunakan daun Begonia hirtella.

Begonia dikenal dengan nama daerah hariang bulu (Sunda) (Subro, 2012). Nama populer B. hirtella adalah B. peludinha, nama yang umum Brazilian begonia. Nama lainnya $B$. brasilia de Candolle, $B$. brasiliana Steudel, B. villosa Lindley (Mortellaro et al., 2012; Filho et al., 2013).

Daun B. hirtella dapat digunakan sebagai antifungi karena mengandung senyawa antifungi antara lain fenol, flavanoid, steroid, 
terpenoid dan alkaloid. Senyawasenyawa yang terkandung dalam suatu tanaman dapat diujikan ke mikroba uji dengan cara ekstraksi dengan pelarut non polar ( $n$-heksan), semi polar (etil asetat) dan polar (etanol)

Senyawa antifungi diperoleh dengan menggunakan metode maserasi dengan cara ekstraksi tunggal masingmasing menggunakan $n$-heksan, etil asetat dan etanol. Maserasi tersebut dimaksudkan untuk menyaring senyawa sesuai dengan tingkat kepolarannya pelarut yang digunakan.

\section{METODA PENELITIAN}

Alat

Alat yang digunakan dalam penelitian yaitu: autoklaf, Laminar air flow, rotary evaporatory (Stuart), hot plate (Stuart), gunting, ember, nampan aluminium, blender, saringan ukuran 60 mesh, beaker glass $1000 \mathrm{ml}$, timbangan analitik, labu Erlenmeyer, spidol, buku tulis, tabung reaksi, rak tabung reaksi, pipet ukur, pipet tetes, vortex, stirrer, gelas ukur, karet gelang, lampu bunsen, korek api, masker, handstool, ose bulat, oven, petri dish, mikropipet, yellow tip, drugalsky, kertas cakram $6 \mathrm{~mm}$, kamera, penggaris, panci.

\section{Bahan}

Bahan yang digunakan dalam penelitian meliputi:

a. Pembuatan ekstrak

Plastik bening ukuran $2 \mathrm{~kg}$, daun Begonia hirtella yang tumbuh di Desa Kalisat kidul Kec. Kalibening Kab. Banjarnegara, etil asetat, aquades, kertas saring, Sulfoxide dimetil (DMSO) 5\%, aluminium foil, wrapping, kertas label dan kertas tisu.

b. Uji antimikroba

Saboraud Dekstrosa Broth (SDB), Saboraud Dekstrosa Agar (SDA), biakan C. albicans dan kertas cakram $6 \mathrm{~mm}$.

\section{Rancangan Penelitian}

Penelitian ini menggunakan metode eksperimental Rancangan Acak Lengkap (RAL), dengan perlakuan uji daya hambat menggunakan ekstrak $n$ heksan, etil asetat dan etanol konsentrasi $1000 \mathrm{ppm}$ terhadap $C$. albicans, dengan 4 kali ulangan, diperoleh dari perhitungan menggunakan rumus (Supranto, 2000). $(\mathrm{n}-1)(\mathrm{t}-1) \geq 15$ $(\mathrm{n}-1)(3-1) \geq 15$ $(\mathrm{n}-1)(2) \geq 15$ $2 \mathrm{n}-2 \geq 15$ 
$2 \mathrm{n} \geq 15+2$

$2 \mathrm{n} \geq 17$

$\mathrm{n} \geq 17 / 2$

$\mathrm{n} \geq 9$

sehingga terdapat 18 unit percobaan. Masing-masing perlakuan tersebut adalah sebagai berikut:

$\mathrm{E} 1 \mathrm{~m}=$ uji ekstrak $n$-heksan terhadap $C$. albicans

E2m $=$ uji ekstrak etil asetat terhadap $C$. albicans

E3m= uji ekstrak etanol terhadap $C$. albicans

Keterangan:

$\mathrm{E} 1=$ ekstrak $n$-heksan

$\mathrm{E} 2=$ ekstrak etil asetat

$\mathrm{E} 3=$ ekstrak etanol

$\mathrm{m}=C$. albicans

\section{Cara Kerja}

1. Persiapan dan pembuatan simplisia (Fadhilah et al., 2014) dengan modifikasi

Keseluruhan daun segar beserta tangkai daun tanaman $B$. hirtella dipetik menggunakan gunting lalu diseleksi daun yang terbaik. Daun dicuci dengan air mengalir dengan waktu yang sesingkat mungkin bertujuan untuk menghilangkan pengotor, namun tidak menghilangkan zat berkhasiat simplisia tersebut. Daun ditiriskan dan dipotong kecil-kecil $\pm 3 \mathrm{~cm}$, selanjutnya simplisia dikering anginkan selama 5 hari, lalu dikeringkan menggunakan oven pada suhu $50^{\circ} \mathrm{C}$ selama 2 hari. Setelah daun kering daun dihancurkan menggunakan blender kemudian disaring dengan penyaring ukuran 60 mesh.

2. Ekstraksi (Moningka et al., 2015)

Ekstraksi dilakukan menggunakan metode maserasi dengan tiga pelarut yang berbeda tingkat kepolarannya, yaitu heksana (non polar), etil asetat (semi polar), dan etanol (polar). Perbandingan antara bahan dan pelarut ialah 1:5 (w/v) selama 5 hari sambil sesekali diaduk. Setelah 5 hari, masingmasing sampel tersebut disaring menggunakan kertas saring menghasilkan filtrat 1 dan residu 1 . Residu yang ada kemudian ditambahkan pelarut dengan perbandingan 1:3(w/v) selama 2 hari sambil sesekali diaduk. Setelah 2 hari, masing-masing ekstrak disaring menggunakan kertas saring menghasilkan filtrat 2 dan ampas 2 . Filtrat 1 dan 2 dicampur menjadi satu, kemudian filtrat yang diperoleh dari masing-masing ekstrak diuapkan dengan menggunakan alat rotary evaporator sehingga diperoleh 
ekstrak kental dari masing-masing pelarut

\section{Uji aktivitas antifungi terhadap}

\section{C. albicans}

a. Pembuatan larutan uji masingmasing ekstrak

$$
\begin{aligned}
& \text { Dibuat larutan ekstrak } \\
& 1000 \text { ppm dengan cara } \\
& \text { melarutkan 0,002 gram ekstrak } \\
& \text { dalam } 2 \text { ml DMSO 5\% } \\
& \text { b. Pembuatan larutan stok untuk } \\
& \text { uji variasi konsentrasi }
\end{aligned}
$$

Larutan ekstrak dengan konsentrasi 1000 ppm dibuat dengan melarutkan 0,020 gram ekstrak dalam $20 \mathrm{ml}$ DMSO 5\%

c. Saboraud Dekstrosa Broth (SDB) (Warsinah, et al.,2011)

Ditimbang sebanyak 30 gram SDB, lalu dilarutkan dalam 1 liter aquadest sampai didapatkan suspensi yang homogen dan dipanaskan selama 1 menit. Kemudian suspensi disterilisasi dalam autoklaf pada suhu $121^{\circ} \mathrm{C}$,tekanan 2 atm selama 15 menit.

d. Saboraud Dekstrosa Agar (SDA) (Warsinah, et al.,2011)

Ditimbang sebanyak 65 gram SDA, lalu dilarutkan dalam 1 liter aquadest sampai didapatkan suspensi yang homogen dan dipanaskan selama 1 menit. Kemudian suspensi disterilisasi dalam autoklaf pada suhu $121^{\circ} \mathrm{C}$, tekanan 2 atm selama 15 menit.

e. Penyiapan kultur

Biakan C. albicans yang telah diremajakan, diinokulasikan sebanyak satu ose ke media SDB,selanjutnya kultur diinkubasi pada suhu $37^{\circ} \mathrm{C}$ selama 2 x 24 jam.

f. Uji aktivitas dan antifungi berbagai pelarut (Efendi dan Hertiani, 2013)

Sebanyak $10 \quad \mathrm{ml}$ SDA dimasukkan ke dalam cawan petri kemudian dimasukkan 100 $\mu \mathrm{L}$ mikroba, mikroba tersebut diratakan dengan drugalsky. Diteteskan ekstrak ( $n$-heksan, etil asetat, etanol dan air) sebanyak $50 \quad \mu l$ dengan konsentrasi 1000 ppm pada masing-masing kertas cakram, kemudian kertas cakram tersebut diletakkan di atas media agar. Setelah didiamkan selama 30 menit, cawan diinkubasi pada suhu $37^{\circ} \mathrm{C}$ selama $16-18$ jam. Adanya daerah bening di sekeliling cakram kertas 
menunjukkan adanya aktivitas antifungi. Zona bening tersebut diukur diameternya menggunakan penggaris.

\section{Waktu dan Tempat}

Penelitian ini dilaksanakan di bulan April - Juni 2018 di Laboratorium Mikrobiologi Program studi D-III Analis Kesehatan STIKES Borneo Cendekia Medika Pangkalan Bun.

\section{HASIL DAN PEMBAHASAN}

Hasil uji aktivitas antifungi ekstrak $n$-heksana, etil asetat dan etanol daun B. hirtella terhadap C. albicans menggunakan metode difusi agar Kirby Bauer. Menggunakan kertas cakram berdiameter $6 \mathrm{~mm}$ yang telah disterilkan terlebih dahulu dan setiap kertas cakram ditetesi sebanyak $50 \mu \mathrm{L}$ lekstrak dengan berbagai pelarut konsentrasi 1000 ppm. Zona hambat yang terbentuk diidentifikasi dengan melihat daerah bening di sekeliling cakram dan besarnya zona hambat diketahui berdasarkan pengukuran diameter daerah bening tersebut. Hasil pengukuran diameter zona hambat masing-masing ekstrak terhadap $C$. albicans diperoleh rata-rata zona hambat ekstrak $n$-heksan (12 mm), ekstrak etil asetat $(13 \mathrm{~mm})$ dan ekstrak etanol $(12.5 \mathrm{~mm})$. Setiap ekstrak mempunyai zona hambat yang berbedabeda dipengaruhi oleh sifat pelarut dan zat terlarutnya, yang dapat mempengaruhi aktivitas terhadap mikroba uji.

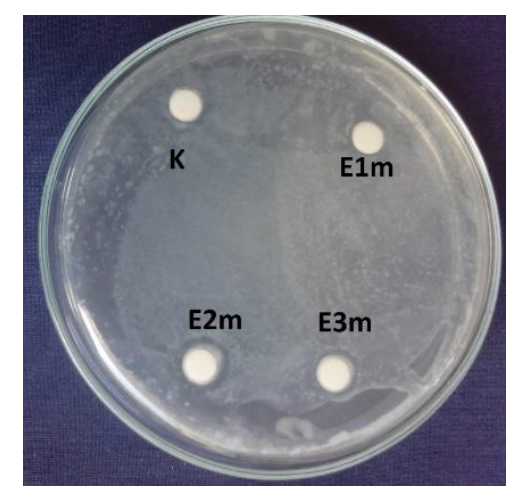

Gambar 4.1 Zona hambat ujianfungi kontrol negatif $(\mathrm{K})$, ekstrak $n$-heksan (E1m), ekstrak etil asetat (E2m) dan ekstrak etanol (E3m) terhadap C. albicans

Gambar 4.1 menunjukkan pada kontrol negatif tidak membentuk zona hambat. Kontrol negatif uji aktivitas antimikroba menggunakan DMSO 5\%. DMSO digunakan karena kemampuan difusi DMSO yang baik pada media agar dan tidak memberikan daya hambat (Purwanti et al., 2014).

Ekstrak $n$-heksana menunjukkan adanya aktivitas antibafungi yang paling kecil dibandingkan dengan ekstrak lain. Ekstrak n-heksana melarutkan senyawa minyak. Senyawa minyak atsiri dan lipida lainnya mempunyai ukuran molekul besar et 
al.(1995); Moningka et al. (2015). Sedangkan hasil penelitian menunjukkan ekstrak etanol mempunyai zona hambat yang lebih besar dibandingkan ekstrak $n$-heksan. Menurut Rahminiwati et al., (2011) ektrak etanol dimaksudkan agar semua senyawa kimia baik yang kurang polar, semi polar sampai polar dapat terekstraksi semaksimal mungkin.

Ekstrak etil asetat mempunyai zona hambat terbesar dibandingkan dengan pelarut yang lain. Salah satu senyawa yang terdapat pada etil asetat adalah saponin. Saponin sebagai antifungi menyebabkan kebocoran protein dan enzim di dalam sel. Saponin bersifat sebagai surfaktan yang berbentuk polar akan menurunkan tegangan permukaan membran sterol dari dinding sel $C$. albicans, sehingga menyebabkan gangguan permeabilitas membran yang berakibat pemasukan bahan atau zat-zat yang diperlukan dapat terganggu akhirnya sel membengkak dan pecah (Luning et al., 2008 dalam Fitriani et al, 2013).

Selain mengandung polifenol, ekstrak etil asetat juga mengandung fenol. Mekanisme senyawa fenol sebagai antifungi yaitu berinteraksi dengan dinding sel fungi, dimana pada kadar yang rendah akan mendenaturasi protein dan pada kadar yang tinggi akan menyebabkan koagulasi protein sehingga sel akan mati (Siswandono dan Sukardjo,1995 dalam Lidyawita et al, 2013).

\section{KESIMPULAN}

Berdasarkan penelitian dapat disimpulkan bahwa:

1. Jenis pelarut ekstrak $n$-heksan, etil asetat dan etanol daun $B$. hirtella berpengaruh terhadap zona hambat $C$. albicans

2. Pelarut yang mempunyai penghambatan terbaik adalah ekstrak etil asetat

\section{SARAN}

Perlu dilakukan penelitian lebih lanjut mengenai:

1. Mikroba yang digunakan untuk uji lebih bervariasi

2. Dilakukan uji senyawa ekstrak etil asetat daun $B$. hirtella yang diduga berperan sebagai antibfungi $C$. albicans

\section{DAFTAR KEPUSTAKAAN}

Aldi, Y., Mahyudin dan D. Handayani. 2013. Uji Aktivitas Beberapa Subfraksi Etil Asetat dari Herba Meniran (Phyllanthus niruri Linn.) terhadap Reaksi 
Hipersensitivitas Kutan Aktif. Jurnal Sains dan Teknologi Farmasi. 18 (1): 9-16.

Alexopoulos, C. J., C. W. Mims dan M. Blackwell. 1996. Introductory Mycology. John Wiley \& Sons inc, USA.

Anonim. 2016. Australian Tropical Rainforest Plant. (On-line), http:// keys.trin.org.au/ keyserver/ data/0e0f0504 -0103430d- 8004060d07080d04/media/Html/ta xon/_Begonia_hirtella.htm diakses 8 Februari 2016.

Blasco, F. A., G. Q. D. Guzman dan G. J. D. Alejandro. 2014. A Survey of Ethnomedicinal Plants in Surigao Del Sur Mountain Range, Philippines. Int. J. Pure App. Biosci. 2 (4): 166-172.

Brooks, G. F. 2007. Jawetz, Melnick, \& Adelberg's Medical Microbiology Twenty-Fourth Edition. McGraw-Hill, USA.

Bustanussalam, H. Susilo dan E, Nurhidayati. 2012, Identifikasi Senyawa Dan Uji Aktivitas Ekstrak Etil Asetat Kulit Kayu Massoi (Cryptocarpa massoy). Fitofarmaka. 2 (1): 67-76.

Daniel. 2010. Isolasi dan Identifikasi Senyawa Flavonoid pada Fraksi Etil Asetat dari Daun Tumbuhan Sirih Merah (Piper crocatum Ruiz \& Pav). Mulawarman Scientifie. 9 (1): 17-26.

Das, R. D., M. T. Islam, A. S. M. Sale Hin Bin Mahmud, M. H. Kabir,
M. E. Hasan, Z. Khatun, Md. M. Rahman, M. Nurunnabi, Y. $\mathrm{K}$ Lee, R. Jahan, M. Rahmatullah. 2012. An Ethnomedicial Survey Conducted Among the Folk Medicinal Practitioners of Three Villages in Kurigram District, Bangladesh. American-Eurasian Journal of Sustainable Agriculture. 6 (2) : 85-96.

Efendi, Y. N. dan T. Hetiani. 2013. Potensi Antimikroba Ekstrak Etanol Sarang Semut (Myrmecodia tuberosa Jack) terhadap Candida albicans, Escherichia coli dan Staphylococcus aureus. Trad.Med.J. 18 (1): 53-58.

Fadhilah, H., H. Rivai dan R. Yuandina. 2014. Pembuatan dan Karakterisasi Ekstrak Kering Daun Jambu Mete (Anacardium occidentale L.). Prosiding Seminar Nasional dan Workshop "Perkembangan Terkini Sains Farmasi dan Klinik IV", Padang.

Filho, P. J. S. D. S, C. C. D. Silva, F. P. Franco, J. Cavalli, L. M. Bertholdo, L. A. Schmitt, R. Ilha dan C. A. Mondin. 2013. Levantamento Floristico de um Fragmento de floresta Ombrofila Densa no litoral norte do Rio Grande do Sul, Brazil. Brazilian Journal of Biosciences. 11 (2): 163-183.

Fitriani, E., M. Alwi. dan Umrah. 2013. Studi Efektivitas Ekstrak Daun Sereh Wangi (Cymbopogon nardus L.) Sebagai Antifungi 
Candida

albicans.

Biocelebes.7 (2): 15-20.

Gandjar, I., R. A. Samson, K. V. D. T. Vermeulen, A. Oetari dan I. Santoso. 1999. Pengenalan Kapang Tropik Umum. Yayasan Obor Indonesia, Jakarta.

Girmansyah, D. 2014. Begonia hirtella Link di Jawa. LIPI: Cibinong Bogor.

Hartutiningsih dan M. Siregar. 2008. Mengenal dan merawat Begonia. PT Agro Media Pustaka, Jakarta.

Lidyawita, R., Sudarsono dan Harsini. 2013. Antifungal Activities of Boiled Cashew Bark (Anacardium occidentale L.) on $C$. albicans In Acrylic Resin. Trad. Med. J. 18 (1): 46-52.

Mandal, B. K., E. G. L. Wilkins, E. M. Dunbar dan R. T. M. White. 2004. Penyakit infeksi. Terjemahan oleh J. Surapsari. 2008. Erlangga, Jakarta.

Moningka, K. C., N. S. Kojong dan S. Sudewi. 2015. Uji Aktivitas Antibakteri Ekstrak Daun Ekor Kucing (Acalypha hispida Burm. F.) terhadap Bakteri Staphylococcus aureus dan Escherichia coli secara InVitro. 4 (3): 193-202.

Nagariya, A. K., A. K. Meena, D. Jain, B. P. Gupta, A. K Yadav, M. R. Gupta, A. K Pathak dan Neelam. 2010. Medicinal Plants Used in the Healing of Skin Diseases in Different
Regions of India: A Review. International Journal of Chemical and Analytical Science. 1 (5): 110-113.

Neal, M. J. 2006. At a Glance Farmakologi Medis. Terjemahan oleh Juwalita Surapsari. Erlangga, Jakarta.

Nurrani, L., S. Tabba dan H. S. Mokodompit. 2015. Kearifan Lokal dalam Pemanfaaatan Tumbuhan Obat oleh Masyarakat di Sekitar Taman Nasional Akatejawe Lolobata, Provinsi Maluku Utara. Jurnal Penelitian Sosial dan Ekonomi Kehutanan. 12 (3): 163-175.

Osbourn, A. E. 2003. Saponin in Cereal. Phytochemistry. 62 (1): 1-4.

Purwanti, L., A. Maharani dan L. Syafnir. 2014. Uji Aktivitas Antibakteri dan Isolasi Alkaloid dalam Daun Tomat (Lycopersicon esculentum Mill.). Prosiding Seminar Nasional Penelitian dan PKM Sains, Teknologi dan Kesehatan, Unisba.

Sie, J. O. 2013. Daya Antioksidan Ekstrak Etanol Kulit Buah Manggis (Garcinia mangostana Linn) Hasil Pengadukan dan Reflux. Calyptra. 2 (1): 1-10.

Subro, I. L. 2012. Struktur Komunitas Tumbuhan Bawah di Kawasan Hutan Taman Nasional Gunung Halimun- Salak, Jawa Barat. J. Tek. Ling. Edisi Khusus "Hari Lingkungan Hidup" :57-67 
Supranto, J. 2000. Statistik Teori dan Aplikasi. Jilid 1 Edisi 6. Erlangga, Jakarta.

Tsuzuki, J. K., T. I. E. Svidzinki, C. S. Shinobu, L. F. A. Silva, E. D. Filho, D. A. G. Cortez dan I. C. P. Ferreira. 2007. Antifungal Activity of The Extracts and Saponins From Sapindus saponaria $\mathrm{L}$. Anais $d a$ Academia Brasileira de Ciência. 79 (4): 577-583.

Tyasrini, E., T. Winata dan Susantina. 2006. Hubungan Antara Sifat dan Metabolit Candida spp. Dengan Patogenesis Kandidiasis. JKM. 6 (1): 5267.

Warsinah, E. Kusumawati dan Sunarto. 2011. Identifikasi Senyawa Antifungi dari Kulit Batang Kecapi (Sandoricum koetjape) dan Aktivitasnya terhadap Candida albicans. Majalah Obat Tradisional, 16(3): 165-173. 